\title{
Comprehending Poverty in Rural Indonesia: An In-depth Look inside Paddy Farmer Household in Marginal Land Area of Banyuasin District, South Sumatra Province
}

\author{
Nina Lisanty ${ }^{1}$, Hiromi Tokuda ${ }^{2}$ \\ ${ }^{1}$ Graduate School of Bioresources, Mie University, Japan. \\ ${ }^{2}$ Bioresources Faculty, Mie University, Japan. \\ Correspondence: Nina Lisanty, Graduate School of Bioresources, Mie University, Tsu City Kurimamachiyachou 1577, \\ Mie Prefecture, Japan.
}

Received: February 25, 2015

Accepted: March 12, 2015

Available online: April 15, 2015

doi:10.11114/ijsss.v3i3.686

URL: http://dx.doi.org/10.11114/ijsss.v3i3.686

\begin{abstract}
Indonesia's steady economic growth in recent decade has led to a gradual reduction in overall poverty in the country. However, according to The World Bank (2011), 43.3 percent of Indonesians live on less than $\$ 2$ a day. The majority of those poor live in rural area and earn their primary income from agriculture. Through an in-depth look inside the poor farmer households of the marginal land of South Sumatra, Indonesia, this paper exposes that in spite of being food producers, the farmer households are food insecure. They also do not have adequate income and employment in the area. The natural state of the area and the unequal social order in the country are among the roots of poverty. The Government's role in terms of poverty reduction should be strengthened. The current need of the farmers regarding this issue is the regulation on laborer wage and on the practice of bonded labor and moneylenders.
\end{abstract}

Keywords: poverty, poor farmer, marginal land, food insecurity

\section{Introduction}

A famous Dutch writer Multatuli (pen name of Eduard Douwes Dekker) in his book Max Havelaar (1860) wrote,

"Famine------? In Java the rich and fertile, famine?"------ Yes, reader, a few years ago whole districts were depopulated by famine; mothers offered to sell their children for food, mothers ate their own children. -----(p. 68-69)

Multatuli explained about the abject poverty and starvation among the farmers in the Dutch East Indies (present-day Indonesia) as the result of widespread abuse of Dutch colonial power. Today, 69 years since its independence from colonial rule for more than 3.5 centuries, Indonesia has been struggling to move forward. Indonesia's economy continues to grow steadily, and it has now achieved the status of a middle-income country. Data from Badan Pusat Statistik [BPS] $\left(2012^{\mathrm{a}}\right)$, the Government's Central Statistic Agency, proved that steady economic growth has led to a gradual reduction in overall poverty in the country, which has fallen from 17 percent in 2004 to 12.5 percent in 2011. However, The World Bank (2011) stated that 43.3 percent of Indonesians live on less than $\$ 2$ a day.

United Nations (UN) Statement on June 1998, signed by the head of all UN Agencies, defined poverty as a lack of basic capacity to participate effectively in society. It means not having enough to feed and cloth a family, not having a school or clinic to go to, not having the land on which to grow one's food or a job to earn one's living, not having access to credit. It means insecurity, powerlessness, and exclusion of individuals, households, and communities. It means susceptibility to violence, and it often implies living on marginal or fragile environments, without access to clean water or sanitation.

Rural Poverty Portal (2012) confirmed that 16.6 percent of rural people are poor compared with 9.9 percent of the urban population. This means that there are millions of small farmers, farm workers, small breeders, and fishermen who are very poor. For decades, the Indonesian Government's main goal in the agriculture sector has been focusing on how to improve the nation's production, yet it left the main actors, producers and farmers to contend with poverty. Poverty is increasingly concentrated in rural areas where more than half of the population live and agriculture is the main source of 
income. The poor often live in isolated areas and lack access to markets and agricultural extension services. Their production focused on subsistence needs, yet up to the present moment, migration to urban centers is their only way to surmount poverty.

South Sumatra is one of four provinces in Indonesia where the majority of citizens is categorized as very poor, according to the 2011 census. Despite this, the province has many potential land resources available, ranging from irrigated land, rain-fed, tidal marshes, lowland, and upland. One of its largest rice-producing areas is Banyuasin Regency. It produced 882,597 tons of wetland and 200,980 tons of dryland paddy in 2012, both contributed 30.35 percent to Gross Regional Domestic Product (GRDP) (BPS, 2012 ${ }^{\mathrm{b}}$ ).

Meanwhile, it has a population of 876,000 poor people, 11.27 percent of the total population (BPS, $2012^{c}$ ). The majority of those poor is paddy farmers. They own a small plot of land, coupled with the condition that the land can be planted only once in a year, while most of the paddy field in the province can be planted five times in two years. Their income is mostly allocated to pay debt to loan sharks, which further aggravates their financial condition. Farmers always confront the choice of whether to consume or sell more rice to meet their needs of non-rice consumption.

In recent years, Indonesian mass media have been intensely broadcasting news about urban poverty. Furthermore, TV stations commercialized poverty by producing many reality shows portraying how the urban poor endure daily life. Notwithstanding that, most of the population is not aware that the majority of people in rural areas is living in even more severe poverty. Through an in-depth look inside the Banyuasin poor farmer households, this paper explores their socioeconomic condition, including their household food consumption. Through the analysis of their socioeconomic condition, this paper examines multiple facets of poverty those farmer households encounter in their life, including food insecurity, inadequate income and employment, and inability to keep pace with modernization and social exclusion. Finally, this paper analyzes the roots of poverty in rural Indonesia and discusses the Government's role in it. It is hoped that this paper can contribute as another piece of literature to urge the Government to be more precise and wise in targeting their programs and to formulate alleviation strategies.

\section{Method}

A research was conducted from December 2013 to January 2014 in the Muara Telang Marga Village, Muara Telang District, Banyuasin Regency, South Sumatra Province, Indonesia. The research site was purposely chosen (purposive sampling), with consideration that the district was a rice surplus region, while having the highest poverty in the regency (BPS, $2012^{c}$ ). According to census data of Banyuasin Regency, 575 of 627 households in the Muara Telang Marga Village were poor. As the population was relatively homogeneous (most of them was farmers), 60 poor households were selected as the samples, organized by a simple random method (simple random sampling). The collected data included primary and secondary data. The former was obtained by conducting a survey and interviews of samples by using a questionnaire consisting of questions related to food consumption as to the type of food consumed, quantity, food price, average family income, number of family members, and education level. The latter consisted of a monograph of the research site, production of rice and other food, and other data related to the research.

\section{Results and Discussion}

It is well known that the primary cause of poverty is lack of income. However, income level is just one single cause. It is less well-known that lack of access to basic goods and services also are responsible for poverty. Shortcomings and limitations in a certain region comprise a chain of cause and result in the poverty of its population (Gordon, 2005). For instance, income opportunities dwindle when access to market and employment centers are inadequate. Deficient access to education contributes to poorly educated people. Lack of access to sufficient health services and basic needs, such as food and clean water, induce maladies. Lack of access to information, of agricultural techniques for example, can lead to stagnant productivity.

Generally, those mentioned above are the major hindrances for many people in the research area. These poor communities are isolated not only in physical terms but also in terms of their access to employment, financial resources, skills, and information. In this section, the in-depth look inside the poor farmer households explores their socioeconomic condition illustrating their poverty level.

\subsection{The In-depth Look Inside Poor Farmer Household}

The Muara Telang Marga Village is located in a tidal marsh lowland area, covering a flat topography of 4,500 hectares with the altitude around $50 \mathrm{~cm}$ above the sea level. The distance from the closest district capital is $45 \mathrm{~km}$ and takes approximately 1 hour 15 minutes using a speedboat, while the distance from the nearest urban area is $150 \mathrm{~km}$ and takes around 3 hours also by speedboat. The village area is relatively isolated, surrounded by a river and a forest. The river contains brine and therefore the villagers cannot use it for drinking water. They use rainwater instead. Rainfall ranges from $2,300 \mathrm{~mm}$ to $2,500 \mathrm{~mm}$ per year, with average temperature ranges of about $15^{\circ} \mathrm{C}$ to $38^{\circ} \mathrm{C}$. During the dry season, 
villagers have to find a source of clean water in the forest.

All of the villagers, including the respondents, were transmigrants from Java Island. They have been living in the area since 1969 or 1980s. Based on the survey, 81.67 percent of the respondents owned land for paddy field of $0.20-0.80$ hectares on the tidal wetland and or rain-fed lowland area, while the rest were sharecroppers. The majority of these poor farmers (66.67 percent) owned a relatively small and infertile plot of land, alleged marginal land. They employed traditional techniques of paddy cultivation using simple tools and manuals. Unlike irrigated paddy farming, rain-fed and tidal marsh paddy farming is cultivated only once a year, starting from December to May. The farmer, head of the household, depended mainly on the rainy season to manage their land drainage without any technical irrigation available. Valuable assets other than land owned by household respondents were livestock and small wooden boats. They used boats to catch fish or as a means of transportation. However, just as with the land, not all households owned livestock or boats. 41.67 percent of these poor households owned hens, with the average amount of ownership of 5.21 individuals per household; while 26.67 percent owned boats.

Another poverty indicator was reflected in their housing condition. The houses did not have the flooring or used cheap wood flooring and had a thatched roof. The floor area was less than 8 square meters per person. Walls were made of bamboo, thatch, low-quality wood or walls without plaster. Most of the houses did not have facilities to defecate. The local government built shared toilets and washing rooms for the villagers in certain locations. However, because some villagers had to walk some distance along the narrow banks of sewage canals to communal bathing facilities, they initiated to make a special place and used it as a shared facility with other households nearby. Electric lighting was rare in the area, only 20 percent of respondents utilized electricity as the lighting source, while others used one or two kerosene lamps. The children, if they were lucky enough to go to school, gathered around the lamp and did their homework on the floor. The members of the family slept side by side also on the floor, with thin and worn woven leaves mat without a mattress and only pillows. Everything in the house was done on the floor. The rainy season was certainly a blessing for their paddy field, but not for their houses. Particularly in the rainy season, heavy rainfall flooded the area for days. For those living close to the river, their houses were flooded knee-deep. They were forced to flee to a relative's house, mosques, schools or public facilities, and shelters provided by the local government until the flood receded. For the rest, the rain soaked the ground, forcing them to sleep on a bench, while apart from the bench there was only a rack for clothing and a rack for dishes in their houses.

Rubbish was the major environmental issue of the area. The villagers threw everything into the river, dirty canals, or empty spaces around their houses. Poor sanitation made it harder to have a decent life. Mosquitoes, fleas, heat, and filth crowded the air and they were among the diseases' carriers; in the houses of some of the respondents, there was often an ill person lying in the background.

Many respondents could not read, write, or sign their names. They were embarrassed to write and with difficulty they held a pen and tried to write their name. They also had difficulty communicating. Some hardly looked into the eyes, but down and away, making it hard to have a conversation. When asked about their background and history, they looked blank as though they had no memory. They spoke in a mixture of dialects, they mumbled sentences, but could not explain their problems. Moreover, they lacked time, could not talk for long, as they had to work all day for the family. At night, they seemed too exhausted to talk about their activities.

Public facilities and infrastructure in the village were inadequate. The village had only one health center, namely Posyandu. For educational facilities, the village had only one unit primary school, which required the villagers to go to other nearby villages to get an advanced educational level.

\subsection{The Multiple Facets of Poverty}

Interviews with households and individual respondents delineated some aspects of poverty, namely food insecurity, inadequate income and employment, and inability to keep pace with modernization and social exclusion.

\subsubsection{Food Insecurity}

Poverty and food security are two interrelated phenomena. They can be considered to have a causal relationship. A household's food security condition is liable to be a source of poverty, or else, due to poverty a household is food insecure. In addition, there is a parallel relationship between poverty and not having enough food. Nonetheless, as mentioned earlier in the Introduction section, respondents were the main actors in the food industry who were able to produce food for their family despite living in poverty. Whether food security was also an issue in their house is explained below, preceded by the analysis of household food consumption.

Rice is the main commodity for the poor in Indonesia, as rice is the staple food of the population. Staple foods are usually a source of carbohydrates as well as a source of energy. BPS (2013) reported that in March 2013 the percentage of expenditure for rice of a poor household to their monthly expenditure was 23.10 percent, even higher in rural areas, 
26.08 percent. The contribution of rice expenditure to the poverty line reached 34.91 in rural areas and 25.98 in urban areas. Consequently, the increase of rice price brought significant impact to the poor.

As the paddy farmers, the rise of rice price affected their decisions to sell more rice (rather than to consume more), in order to gain more income to fulfill their daily needs. When the rice of price increased, respondents decreased household rice consumption, and consumed more tubers as a substitute. The rice consuming pattern was difficult to change despite households facing failures on their paddy field due to drought, flooding (heavy rainfall), and pests. Respondents' rice consumption on average was $132.59 \mathrm{~kg} / \mathrm{capita} /$ year.

The quantity of rice consumed was higher than national rice consumption of $85.51 \mathrm{~kg} / \mathrm{capita} / \mathrm{year}$ (Statistic Indonesia, 2013). The Food Security Council has found the rice consumption to be $139.15 \mathrm{~kg} / \mathrm{capita} / \mathrm{year}$, when including the use of direct consumption of processed food, industrial, and feed which makes Indonesia the highest quantity of rice consumption in the world. In comparison, the rice consumption of Malaysia, China, Brunei Darussalam, and Japan consecutively were 90, 90-100, 80, and $70 \mathrm{~kg} / \mathrm{capita} /$ year (Nurhayat, 2013).

Numerous studies have shown a statistically significant positive association between total household per capita income and dietary diversity, defined as the number of individual foods or food groups consumed over a given period of time. The close association between income and diets can be shown by using household consumption surveys. Figure 1 presents the analysis of household survey, showing the less than $\$ 1$ income households (A), $\$ 1$ to $\$ 2$ income households (B), and more than $\$ 2$ income households (C) according to per capita income, compared with the percentage of South Sumatra regional shares of food groups in total dietary energy supplies. The survey results confirm that diets in the higher-income groups are more diversified. As incomes grow, the contribution of rice, other cereals, and tubers to total per capita dietary energy supplies decreases whereas the contributions of animal-source foods and of fruits and vegetables increase significantly. The shifts in diet composition with income are reflected in changes in the availability of nutrients.

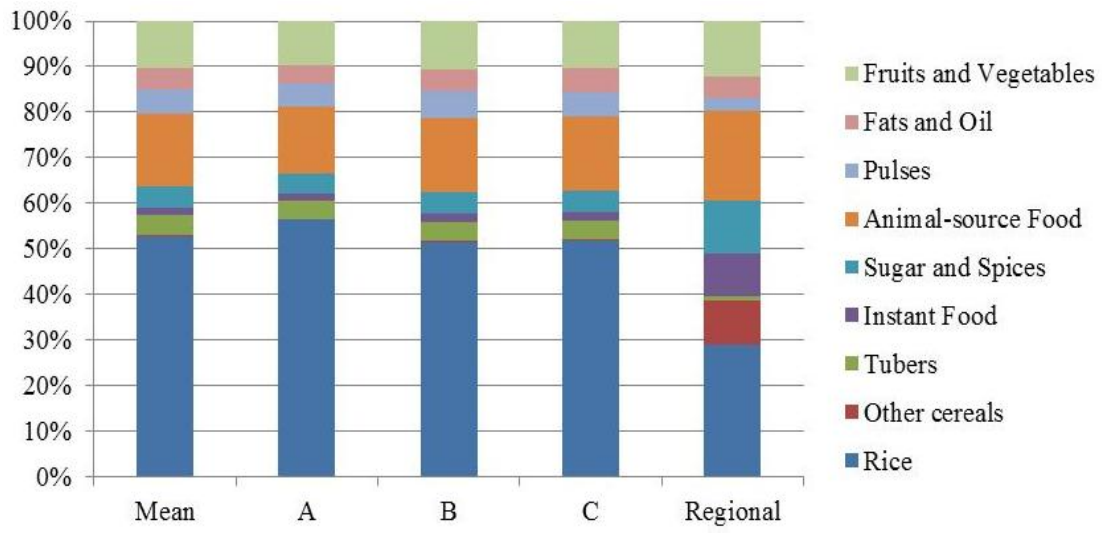

Figure 1. Share of food groups in total dietary energy supplies of poor household farmers in Banyuasin Regency and South Sumatra population (percentage)

Description: Analysis of household surveys (all respondents, Group A, and B) and data of the BPS (2013), calculated (regional)

As shown in Figure 1, the relative importance of carbohydrates from rice, other cereals, and tubers is much smaller in the diets of higher-income households. Tubers were another food energy source of respondents. Respondents consumed tubers as a substitute for rice in terms of its carbohydrate contents. However, the food is poor in protein, which means if it is used as a staple food, it will require extra food that contains enough protein. As for the consumption of tubers, cassava was the most widely consumed by $8.96 \mathrm{~kg} / \mathrm{capita} / \mathrm{year}$. The amount was higher than the average consumption of South Sumatrans, $8.03 \mathrm{~kg} / \mathrm{capita} / \mathrm{year}$ (BPS, 2013). This was due to cassava planting in the yards of most of the respondents. Farmers exploited their yard and paddy field for planting. They preferred to plant cassava because these plants do not need special treatment. Cassava was usually consumed in the form of fried, boiled or steamed and was identified as their breakfast menu. Meanwhile, sweet potato and sago were consumed sequentially $1.94 \mathrm{~kg} / \mathrm{capita} / \mathrm{year}$ and $0.14 \mathrm{~kg} / \mathrm{capita} /$ year as the side dishes. Wheat consumption of $0.79 \mathrm{~kg} / \mathrm{capita} /$ year was as the additional ingredients used to make processed food, particularly at weddings and religious events. Instant noodles were also widely consumed by respondents. When household financial conditions were near a crisis and the household stock of rice depleted, instant noodles were their lifesaver. A mother cooked one pack of instant noodles and divided it into four (or six) portions to be eaten by each member of the family along with rice. Disregarding its poor nutrition, instant noodles were cheap and among family members' favorite foods. 
Conversely, the relative importance of carbohydrates from sugars and other foods is higher in higher-income households, as is the contribution of fats. These are all indicators of a major nutrition transition. There are both positive and negative aspects to these changes. An increase in the share of dietary energy supplies from foods other than staples (for instance animal-source foods, fats and oils, pulses, vegetables and fruits) is generally beneficial to health and nutrition. Increases in the share of fats for people with low fat intake may be good - fats are high in calories and they are required for bio-availability of some micronutrients (those that are fat-soluble). However, for individuals who have higher levels of fat in their diets, a further increase may be detrimental to health. Finally, there is also some increase in the relative contribution of protein to total dietary energy supplies, but this increase is relatively small compared with the other changes.

Consumption of animal-source foods increase significantly as per capita incomes grow. Meat, fish, milk and eggs provide proteins containing a wide range of amino-acids as well as bio-available micronutrients such as iron, zinc, calcium and vitamins A and B12, in which many malnourished people are deficient. Several of these (e.g. iron and zinc) may be difficult to obtain in sufficient amounts from plant-based diets (owing to poor bio-availability). Young children in particular benefit from animal-source foods. However, there are concerns that excessive consumption of meat (especially red meat), dairy products and eggs by older children and adults can have detrimental health effects and increase the risk of chronic non-communicable diseases such as heart disease, cancer, diabetes and obesity. Most of the respondents consumed chicken less than once in a month. As for beef, it was very rarely consumed. Most of the respondents claimed to only consume beef once or twice a year, on religious or special events. Based on the data of Food Security Council of Banyuasin Regency in 2012, the demand for meat was smaller than the production resulting in a surplus. Market mechanisms and distribution of food between locations, relying on stock or inventory, affected the balance between supply and demand, as well as on the market price. The price factor affected household purchasing power. Thus, although the meat commodities were available on the market, because the price was too high and not affordable for the farmers, the farm households could not access the food.

Eggs were generally consumed 1 to 3 times a week. Eggs as the source of animal protein were often consumed in farm households because of its affordability or self-production and practices in its cooking process. Fish were also quite often consumed as they lived around the water areas. The potential and availability of fish made it easy to obtain this kind of food for family consumption, especially for farmers who own a boat.

Plant-based food consumed were in the form of tofu and tempe. Tofu and tempe are processed foods from soybeans. Most of the respondents consumed tofu and tempe one or more times daily. It was because both are 'people food', which were affordable and easy to obtain. However, despite its cheap price, tempe is a food rich in protein. The protein content in 100 grams of tempe is 20 grams, higher than animal protein of 100 grams of beef (19 grams) and 100 grams of eggs (12 grams) (The World's Healthiest Food, 2014).

Fruits and vegetables are an important component of a healthy diet. WHO and FAO recommend a minimum daily intake of $400 \mathrm{~g}$ of fruits and vegetables (excluding potatoes and other starchy tubers); levels lower than this are thought to increase the risk of chronic diseases. An adequate intake of fruits and vegetables also contributes to the prevention of micronutrient deficiencies. From the analysis, it was found that fruit and vegetable consumption tends to decrease with age and increase with income. Various vegetables such as spinach, cassava leaves, papaya leaves, carrots, and peppers were consumed by respondents. The selection of vegetables, was based on preference and availability of raw materials in the market or shops nearby. The most commonly consumed vegetables were spinach and water spinach. $46.67 \%$ of respondents consume spinach as much as 4-6 times per week. Vegetables consumed by farmers were generally derived from their own yard or wild plants growing in a ditch or riverbank. Consumed fruits were in the form of bananas, papaya and citrus. Generally, they consumed fruits 1-5 times a month.

According to the BPS of Banyuasin District (2013), land productivity of the research area was 4.548 tons per hectare. In the case of the minimum ownership of household respondents paddy fields was 0.20 hectares, the production was 909.6 $\mathrm{kg}$ in a single season (4 months). Farmers, according to a previous study conducted in the area (Muriyandi, 2007), particularly sold at least 30 percent of the yield for the next farming capital purposes, to pay debt to the middlemen, and for household food and non-food consumption. It means that the farmers sold $272.88 \mathrm{~kg}$ of the yield and hence the availability of household rice supplies for a year was $636.72 \mathrm{~kg}$, providing $53.06 \mathrm{~kg}$ of rice per month. Assuming a household consists of 6 persons (father, mother, and four children), household monthly consumption is 8.84 $\mathrm{kg} / \mathrm{capita} / \mathrm{month}$.

In the case of the minimum ownership of household respondents paddy fields was 0.80 hectares, the production was $3,638.40 \mathrm{~kg}$. Assuming the farmers sold 30 percent of its production for next farming capital purposes, pay debt, household food and non-food consumption, household rice stock for a year was 2,546.88 kg. Monthly stock was 212.24 $\mathrm{kg}$. The average household member was 6 persons, it means each member can consume $35.37 \mathrm{~kg}$ rice per month. 
The average rice price was IDR 4,000, it means from paddy farming, the 0.2 hectare farmers gained IDR 1,091,520 per year and 0.8 hectare farmers gained IDR 4,366,080 per year. The average household total income, from off-farm and on-farm (other than paddy farming) were IDR 3,569,635 a year. Therefore, total household income of both farmers were IDR 4,661,155 per year or 388,429.58 per month (approximately $\$ 1$ a day) and IDR 7,935,715 per year, or $661,309.58$ per month (almost $\$ 2$ a day) subsequently. Such condition coupled with insufficient household food stock (from their own production) results in a low level of household food availability. Food availability is the first components of food security. Other than that, food accessibility of respondents was also very low. In recent years, as one of the programs in alleviating poverty in urban and rural areas, the government provided cheap rice (and even free in some remote areas) for the poor. However, the distribution at the regional level (county and regency) was often uneven. Poor facilities and infrastructures made it difficult for food (including other goods and services) to be marketed and distributed in the area. Once the products reached the local market, the price was no longer affordable for the poor households. It also resulted in food instability in the market.

Disregarding the food instability, food quality and safety were also far below the standard. The bitter fact that lack of access to education resulted in the low knowledge of nutrition and balanced daily diets. The poor worked hard to fill their stomach regardless of the food quality. Conclusively, four out of four components of food security, namely food availability, accessibility, stability, and quality, could not be met. This signified ultimately the lowest degree of food security, which encouraged pauperism.

\subsubsection{Inadequate Income and Employment}

Since 2010, 80 percent of the respondents have received direct cash assistance from the BLT Program, a special government program addressed to alleviate poverty, as much as IDR 1,200,000 (equals to \$100) per year per household. A monthly IDR 100,000 cash assistance was assuredly not enough for the household of six members (on average) consisting of a father, mother, and four children. The father, the household head, worked hard for the family by engaging in many income earning activities over a year besides being a paddy farmer. Although typically housewives, the mothers helped to manage the paddy fields as well as participated as farm laborers. Income from paddy farming was still not able to meet family daily needs.

Chambers (1995) stated that the poor usually have diverse and often complex strategies to improvise and sustain their living through their livelihood capabilities. Swift (1989) asserted livelihood strategies of the poor in rural areas to increase income, reduce vulnerability, and improve their life quality through tangible assets in the form of stores and resources, and through intangible assets in the form of claims and access. However, the poor in the current research area had limited control of land and other assets, forcing the whole family to work to meet their needs. All of the household members become job seekers, with no exception for members who are still under the working age $(<15$ years old $)$ and the elderly ( $>65$ years old). 8.25 percent of family members under the working age and 4.55 percent elderly people were still working. Other than becoming farm laborers, they were not reluctant to migrate to urban centers and seek jobs by selling their unskilled labor as domestic helpers, construction workers, guards, parking attendants, or shop waitress. It is not uncommon for the household respondents to earn a single-income. Respondents believed households that had more than one working adult were in a stronger economic position because they had an opportunity to combine resources as a strategy for survival.

\subsubsection{Inability to Keep Pace with Modernization and Social Exclusion}

Townsend's concept of relative poverty (Townsend, 1985; Townsend, 1993) related well to the socioeconomic conditions of the poor in the research area. Poverty is usually associated with underdevelopment and backwardness. As a part of the poverty alleviation program, the national government through the Women's Family Welfare Organization empowered rural low-income women by teaching "modern" behavior to them, including practicing religion on a regular basis, wearing different clothes at home and in public, and using the excess income for recreational purposes. Most respondents' standard of living has improved over their lifetimes and hence their poverty is associated with an inability to keep pace with these changes. As an example, despite the increase in standards of living only 8.3 percent household respondents owned television and 26.23 percent owned cellular phones.

Respondents also discussed their inability to participate in local social obligations. Common social activities (or customs) usually included purchasing a wedding present or giving money in an envelope to a family that had experienced tragedy, making a contribution to the Independence Day festivities or a community improvement project, participating in meetings of local community organizations that require monthly dues, and participating in the local credit programs. When the poor household had a celebration to attend, they would want to contribute. However, when they felt that it was a burden, they would think even for themselves sometimes they did not have enough, or barely enough. In turn, poor household avoided participation not only because they could not afford to contribute their time or money, but because their poverty was humiliating and depressing. Consequently, social exclusion is a further barrier to 
opportunities which counteract poverty.

\subsection{The Roots of Poverty in Rural Areas and Government's Role}

According to the published literatures on rural poverty (Otsuka, K., et al., 2009; Dercon, S., 2009; Janvry, A., et al., 2002; and Haynie, D.L., et al., 1999), there are at least three distinctive approaches discerning the source of poverty in rural areas. First, since poverty occurs due to the natural environment, for instance infertile soil, less suitable climate for farming, natural disasters, disease outbreaks, and or water scarcity, it is called the environmental approach. In the research area, most of the population is poor due to infertile marginal land. Before the massive transmigration programs undertaken by the Government in the 1960s and 1970s, which saw the mass exodus of millions of people from Java to Sumatra to ensure equal distribution of the population, the research area and the surrounding marsh tidal areas were uninhabited wilderness areas. The Government has designed the areas in such a way to be habitable. The Government set up hundreds of hectares of paddy plots and built appropriate housing for migrants who were mostly farmers in Java. The farmers had certainly adequate experience to start a business and new life in the new place, but the natural state of the island of Java and Sumatra is divergent making them overwhelmed and struggle to this day to survive.

Second, the mentality of the people in rural areas is argued to be the root of poverty, so called in the cultural approach. It is broadly believed that the people who are persistent, hardworking, frugal, and rational thinking will not be trapped in poverty. Nevertheless, there are always people who work hard, save money, and take into account rational choices, but are still in the poor condition because "to be rich channels" are not open for them. Indeed, through the in-depth look inside the household during the research, many of the poor were seen lazing, chatted with fellow neighbors for hours, slept during the day, or did something less meaningful. It is easy to judge them as a lazy bunch of people who are poor because of their own laziness. However, jobs in rural areas are time sensitive. There is a certain period of crop farming, for example, from planting to harvesting that also usually only requires a few workers. For other kinds of jobs, one must have capital or a network. Not everyone has the money to trade or have a handyman acquaintance to be a construction worker. Thus the strategies of the poor are sleeping a lot and eating little. They think sleep can delay hunger. They did very little not being lazy, but as a strategy to save calories. Not all the poor were able to eat three times a day. Some often actually did not eat for two days in a row.

Finally, the third approach surfaced, stating that the root of poverty is at the unequal social order. This approach is known as the structural approach, where the inequality in the society benefits some and disadvantage others. At the transnational level, many people believe that international institutions such as the WTO (World Trade Organization), IMF (International Monetary Fund), or the World Bank ensnared poor countries through debt in order to control their governments to adopt policies that benefit rich countries and investors. At the domestic level, the Government policies prioritized the interests of industrial capitalists in the cities rather than rural people. At the village level, the Governments implemented policies that benefit village elites rather than the rural farm workers and small-scale farmers (Winarno, 2003). There has been polarization of the source of wealth ownership in rural Indonesia. The rural population was divided into two poles, the rich and the poor. It was not uncommon for the rich to buy or take the land from the poor who owe but could not pay back. The unavailability of credible credit institutions for farmers in rural areas led them in debt at very high interest loans to loan sharks. The major debt suppressor for them was the possibility of crop failure, or a seriously ill family member. Based on the in-depth interview, the loan interest of the loan sharks in the research area has reached 50 percent. The availability of Badan Urusan Logistik (Bulog), the Government Logistic Agency, helped the farmers to overcome the problems of debt and sale of their agricultural products. However, in many cases Bulog partners have created new bonded labor system in rural areas and it has been firmly rooted since long time ago. Bulog partners, who are mostly rural elites or agriculture extension workers, facilitated farmers to get farming inputs and assistances, but instead, farmers had to sell their crops to Bulog partners with the price determined by Bulog and its partners. Due to the abundance of job seekers yet few jobs available, the poor farmers tend to be low-paid.

Meanwhile, many of the poor children do not go to school because education is expensive. Since 2007, the Government has issued BOS, literally school operational costs, the assistance for students. However, this program cannot be enjoyed by the poor children because the targets are current students, while they cannot afford even to begin being a student. BOS simply replaces the school fee while the other costs still have to be paid. In spite of education being crucial for enabling the poor in society, in fact the channels for them are relatively narrow. Accordingly, the situation in rural society in the present day is the decrease of rich people and the increase in the number of the poor.

The Government is responsible for the poverty of its citizens. Policies that benefit a handful of the rich needs to be changed, and the Government must be pro-poor. For instance, the cheap-rice price policy clearly does not benefit farmers. The Government monopolized grain prices. Every time the rice price rose, the Government immediately conducted market operations or imported rice (Suksmantri, 2005). Meanwhile, when fertilizer became rare because the distributors stockpiled it, the Government did nothing. 
If the price of rice is cheap, who benefits? The answer is investors. The price of rice is the benchmark whether to raise the minimum wage. When the rice price is cheap, the minimum wage can be suppressed as much as possible. When the wage is low, employers benefit the most. Therefore, in such case, the Government alignment to the poor is needed. Another example is farm credit. Farm Credit is given to farmers through farmer groups. Members of the group who benefit are those who have land available for credit for seeds, fertilizers, or pesticides. Unfortunately, the poor in rural areas are mostly farm workers who do not own land. They also do not benefit from farm credits. Until now there are no laws that govern wage of these farm workers or laborers. Large industrial workers can demand the minimum wage because there are rules of it, while the farm workers do not.

Marxists considered revolution as the way out. However, revolution is always detrimental to the poor. For example, the Bolshevik revolution, the Khmer Rouge revolutionary behavior, or the behavior of the Maoists in Nepal, all tortured the poor. When more and more people are destitute and their indigence worse, radical ideologies will also grow easily. The Government's role in terms of poverty reduction should be strengthened. Policies should be in favor of the poor. The regulation on laborer wage, as an example, should be issued to discipline the rich farmers not to arbitrarily exploit farm workers. There should also be rules that protect poor farmers from the practice of bonded labor and moneylenders. The Government should manage strict rules about that, and gives solution to the loan problems of the poor. Additionaly, religious institutions such as the zakat (Islamic charity obligations from those that have to those that need) should also be encouraged to protect the poor from adversity. Zakat is organized not only to build mosques, but also mainly to help the needy and poor. Charitable institutions should not be used as a source of livelihood of the commissions, but to help the indigent and poor communities, not only in the city, but also in the villages.

\section{Conclusion}

The image in the minds of most Indonesians when they hear the word "village" is grandfather's house, where a vast expanse of paddy fields is surrounded by mountains and flowing rivers, perfect and beautiful nature and scenery. It is broadly believed that rural people live in the peaceful green hilly areas where the society is friendly and they help each other. Through an in-depth look inside the Banyuasin poor farmer households, the fact of their severe poverty life has been exposed. In spite of being food producers, they are food insecure. Inadequate income and employment worsen their pauperism. Because they fall behind in modernization, they are further alienated from social activities. Indeed, their living place is marginal and infertile, but they are not idlers. The social order is unequal and conditions are never on their side. Therefore, the government should embrace them. They do not just need money, but principally policies to better their lives.

\section{Acknowledgements}

The author would like to thank Mr. Floyd McDaniel and two anonymous international referees for helpful comments on earlier draft. However, the author alone is responsible for any shortcomings and mistakes in this paper.

\section{References}

Badan P. S. (2012). Sosial dan kependudukan, indikator sosial ekonomi, Social and Demographic, Socioeconomic Indicators, 2, Jakarta: Badan Pusat Statistik.

$$
\left(2012^{\mathrm{b}}\right) \text {. Sumatera Selatan dalam angka - tahun 2012, Paddy production and land productivity, }
$$
2012. Jakarta: Badan Pusat Statistik.

$\left(2012^{c}\right)$. Statistik Pertanian [Agricultural Statistics], South Sumatra Province, 2012. Jakarta: Badan Pusat Statistik.

. (2013). Banyuasin dalam angka - tahun 2013 [Banyuasin regency in number - the year 2013], 2013. Jakarta: Badan Pusat Statistik.

Chambers, R. (1995). Poverty and livelihoods: whose reality counts? Environment and urbanization, 7(1), 173-204. http://eau.sagepub.com/content/7/1/173.full.pdf.html , http://dx.doi.org/10.1177/095624789500700106

Dercon, S. (2009). Rural poverty: old challenges in new contexts. Oxford Journals, 24(1), 1-28. http://wbro.oxfordjournals.org/content/24/1/1.html, http://dx.doi.org/10.1093/wbro/lkp003

Gordon, D. (2005). Indicators of poverty and hunger [PowerPoint slides]. http://www.poverty.ac.uk/sites/default/files/indicators-of-poverty-and-hunger_UNpoverty.pdf.html

Haynie, D. L., Gourman, B. K. (1999). A gendered context of opportunity: determinants of poverty across urban and $\begin{array}{llll}\text { rural labor markets. The sociological quarterly, } & 40(2), & 177-197 .\end{array}$ http://dx.doi.org/10.1111/j.1533-8525.1999.tb00544.x http://onlinelibrary.wiley.com/doi/10.1111/j.1533-8525.1999.tb00544.x.html 
Janvry, A., Sadoulet, E., Murgai, R. (2002). Rural development and rural policy. In B. Gardner, G. Rausser (Eds.), Handbook of agricultural economics, 2A., Amsterdam: North Holland.

Multatuli. (1860). Max Havelaar, [The coffee auctions of the Dutch trading company]. English trans. Baron Alphonso Nahuys. Edinburgh: Edmonston and Douglas.

Muriyandi. (2007). Analisis tingkat konsumsi pangan beras rumah tangga miskin dan faktor-faktor yang mempengaruhinya di Kecamatan Muara Telang Kabupaten Banyuasin [The analysis of poor household rice consumption level and its influencing factors in Muara Telang District Banyuasin Regency] (Unpublished Bachelor Thesis). Indralaya: Sriwijaya University.

Nurhayat, W. (2013). Konsumsi beras tertinggi di dunia, orang Indonesia rawan kena diabetes [The highest rice consumption in the world, Indonesians are prone to diabetes]. Detik Finance. Retrieved from http://finance.detik.com/read/2013/07/17/152223/2305835/4/konsumsi-beras-tertinggi-di-dunia-orang-indonesia-ra wan-kena-diabetes.html

Otsuka, K., Estudillo, J. P., Sawada, Y. (2009). Rural poverty and income dynamics in Asia and Africa. New York: Routledge.

Rural Poverty Portal. (2012). Rural poverty in Indonesia. IFAD (International Fund for Agriculture Development). Retrieved from http://www.ruralpovertyportal.org/country/home/tags/indonesia.html

Statistics Indonesia. (2013). Indonesian National Socioeconomic Survey, 2nd quarter of 2013. Jakarta: Badan Pusat Statistik.

Suksmantri, E. (2005, September 26). Impor beras, kenapa ribut? [Imported rice, why fuss?]. Suara Merdeka, pp. A1

Swift, J. (1989). Why are rural people vulnerable to famine? IDS Bulletin, 20(20), 8-15. http://onlinelibrary.wiley.com/doi/10.1111/j.1759-5436.1989.mp20002002.x.html, http://dx.doi.org/10.1111/j.1759-5436.1989.mp20002002.x

The World Bank. (2011). Data - Poverty headcount ratio at $\$ 2$ a day of (PPP) (\% of population). The World Bank. Retrieved from http://data.worldbank.org/indicator/SI.POV.2DAY.html

The World's Healthiest Foods. (2014). Tempeh. The World's Healthiest Food. Retrieved http://www.whfoods.com/genpage.php?tname=foodspice \&dbid=126.html

Townsend, P. (1985). A sociological approach to the measurement of poverty - a rejoinder to Professor Amartya Sen. Oxford Economic Papers, 37, 659-668.

. (1993). International analysis of poverty. New York: Harvester Wheatsheaf.

Winarno, B. (2003). Komparasi organisasi pedesaan dalam pembangunan, Indonesia vis-à-vis Taiwan, Thailand, dan Filipina. [Comparation of rural organization in development, Indonesia vis-à-vis Taiwan, Thailand, and Phillipine. (pp.14). Yogyakarta, Indonesia: Media Pressindo

\section{(cc) BY}

This work is licensed under a Creative Commons Attribution 3.0 License. 